\title{
Article \\ Modulation by Phosphonium Ions of the Activity of Mitotropic Agents Based on the Chemiluminescence of Luminols
}

\author{
Gemma M. Rodríguez-Muñiz ${ }^{1}\left(\mathbb{D}\right.$, Theodoros Mikroulis ${ }^{2}{ }^{(0)}$, Anna Pantelia ${ }^{2}$, Georgios Rotas ${ }^{2}{ }^{(1)}$, \\ Maria-Consuelo Cuquerella ${ }^{1}$, Georgios C. Vougioukalakis ${ }^{2, *}$ (i) and Miguel A. Miranda ${ }^{1, *(1)}$
}

1 Instituto de Tecnología Química UPV-CSIC, Universitat Politècnica de València, Camino de Vera s/n, 46022 València, Spain; gemrodmu@itq.upv.es (G.M.R.-M.); xecual@gmail.com (M.-C.C.)

2 Laboratory of Organic Chemistry, Department of Chemistry, National and Kapodistrian University of Athens, Panepistimiopolis, 15771 Athens, Greece; theo.mik0@gmail.com (T.M.); annapantelia@gmail.com (A.P.); rotasgiorgos@hotmail.com (G.R.)

* Correspondence: vougiouk@chem.uoa.gr (G.C.V.); mmiranda@qim.upv.es (M.A.M.); Tel.: +30-210-727-4230 (G.C.V.); +34-963877-807 (M.A.M.);

Fax: +30-210-727-4761 (G.C.V.); +34-963-879-444 (M.A.M.)

check for

updates

Citation: Rodríguez-Muñiz, G.M.; Mikroulis, T.; Pantelia, A.; Rotas, G.; Cuquerella, M.-C.; Vougioukalakis, G.C.; Miranda, M.A. Modulation by Phosphonium Ions of the Activity of Mitotropic Agents Based on the Chemiluminescence of Luminols. Molecules 2022, 27, 1245. https://doi.org/10.3390/ molecules27041245

Received: 19 January 2022

Accepted: 10 February 2022

Published: 12 February 2022

Publisher's Note: MDPI stays neutral with regard to jurisdictional claims in published maps and institutional affiliations.

Copyright: (c) 2022 by the authors. Licensee MDPI, Basel, Switzerland. This article is an open access article distributed under the terms and conditions of the Creative Commons Attribution (CC BY) license (https:// creativecommons.org/licenses/by/ $4.0 /)$.

\begin{abstract}
Mitochondria-targeting drugs and diagnostics are used in the monitoring and treatment of mitochondrial pathologies. In this respect, a great number of functional compounds have been made mitotropic by covalently attaching the active moiety onto a triphenylphosphonium (TPP) cation. Among these compounds, a number of molecular detectors for reactive oxygen species (ROS) are based on fluorescent and chemiluminescent probes. In this regard, luminol (probably the most widely known chemiluminescent molecule) has been employed for a number of biological applications, including ROS detection. Its oxidation under specific conditions triggers a cascade of reactions, ultimately leading to the excited 3-aminophthalate (3AP*), which emits light upon deactivation. Hence, the photophysical interaction between the light-emitting species $3 \mathbf{A P} *$ and TPP cations needs to be evaluated, as it can add valuable information on the design of novel emission-based mitotropic systems. We herein investigate the quenching effect of ethyltriphenylphosphonium cation onto substituted 3-aminophthalates. These were prepared in situ upon hydrolysis of the corresponding anhydrides, which were synthesized from 3-aminophthalimides. Steady-state fluorescence and timeresolved experiments were employed for the evaluation of a possible electron transfer quenching by phosphonium ions. Our experimental results confirmed such quenching, suggesting it is mainly dynamic in nature. A minor contribution of static quenching that was also detected is attributed to complex formation in the ground state. Accordingly, the chemiluminescence of luminol was indeed strongly reduced in the presence of phosphonium ions. Our results have to be taken into account during the design of new chemiluminescent mitotropic drugs or diagnostic agents of the luminol family.
\end{abstract}

Keywords: luminols; chemiluminescence; 3-aminophthalates; fluorescence; electron transfer

\section{Introduction}

Mitochondria are acknowledged as the subcellular organelles directly affecting both life, as cell's energy powerhouses, and death, as apoptosis regulators [1-3]. Up to $90 \%$ of cells' energy unit ATP [4] and cytotoxic ROS [5] are generated in mitochondria. As a result, mitochondrial malfunction, causing ROS overproduction, is connected to pathogenesis, such as neurodegenerative diseases, cancer, and diabetes [6-8].

Rendering drugs and diagnostics mitotropic (or mitochondriotropic), that is, achieving organelle-specific accumulation, is a way for monitoring and treating mitochondrial pathologies. The large potential difference between the intermembrane space and the mitochondrial matrix (negative in the matrix) makes delocalized lipophilic cations ideal mitotropic carriers [9]. Among these, triphenylphosphonium cations (TPPCs) stand out, 
both due to their exceptional mitotropic activity and ease of synthesis. In this respect, a great number of active compounds, either drugs or diagnostics, have been made mitotropic by covalently attaching the active compound onto a TPPC moiety [10-13].

The importance of ROS imbalance in oxidative stress-caused pathology has triggered research in sensors for intracellular ROS levels detection. As a result, a number of ROS molecular detectors based on fluorescent and chemiluminescent (CL) probes have been prepared and evaluated [14-17]. Although both are based on light emission, CL probes exhibit advantages, such as a high signal-to-noise ratio and no need for external irradiation [18]. In this regard, luminol, probably the best known CL molecule [19], has also been widely studied in vivo, both as ROS detector, and excitation light source, due to its strong CL, stability, and ease of synthesis [20-23]. Its reaction with ROS (especially superoxide anion) in the presence of a catalyst triggers a chain reaction, ultimately leading to excited 3-aminophthalate (3AP *, Figure 1), which emits light upon deactivation.<smiles>Nc1cccc2c(=O)[nH][nH]c(=O)c12</smiles>

luminol

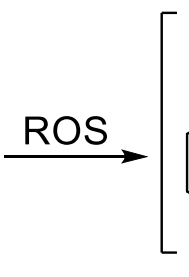

13AP<smiles>Nc1cccc(C(=O)[O-])c1C(=O)[O-]</smiles>

$425 \mathrm{~nm}$

Figure 1. ROS triggered luminol CL reaction, producing 3AP and light.

In the framework of our research towards mitotropic, highly efficient, luminol-based, CL ROS detectors, consisting of covalently attached TPPCs onto luminol via a linker [24], the photophysical interaction between the light-emitting species $3 \mathrm{AP} *$ and TPPC needs to be evaluated as it can add valuable information on the design of novel emission-based mitotropic systems. To the best of our knowledge, the photophysical evaluation of TPPCs as aminophthalate quenchers is presented here for the first time.

\section{Results and Discussion}

We have chosen to investigate the quenching effect of the ethyltriphenylphosphonium (ETPP) cation onto phthalates 1a-c and 3AP (Figure 2). ETPP is a representative mitotropic, delocalized, lipophilic cation, whereas tetramethylphosphonium (TMP) is used here as a reference, non-delocalized cation. Phthalate structures $1 \mathbf{a}-\mathbf{c}$ were chosen in order to evaluate the results pertaining to $\mathbf{A P}$ core substitution, which have been shown to greatly affect the corresponding luminol CL efficiency [25-27]. The preparation of phthalates 1a-c was accomplished as follows: 3 -aminophthalimide 2 was brominated using excess bromine in acetic acid towards phthalimide 3 (Figure 3). This was then functionalized via a SuzukiMiyaura coupling with trimethylboroxine to give the respective dimethyl phthalimide $4 . \mathrm{N}$ Alkylation of $\mathbf{2}$ and $\mathbf{4}$ with 1-iodohexane afforded the $\mathrm{N}$-hexyl derivatives $\mathbf{5 a}, \mathbf{b}$. Hydrolysis of the phthalimides $\mathbf{4}$ and $\mathbf{5 a}, \mathbf{b}$ turned out to be challenging, requiring prolonged reaction times under strongly alkaline conditions. Interestingly, acidic work-up of the crude mixture resulted in the formation of the respective anhydrides $\mathbf{6 a}-\mathbf{c}$, instead of the corresponding phthalic acids, indicating an in situ intramolecular condensation. These anhydrides were found to hydrolyze in basic aqueous media towards the corresponding phthalates $\mathbf{1 a}-\mathbf{c}$, so they were used as their in situ precursors (see Figure S1 in the Supplementary Materials). 
Phthalate Emitters<smiles>[R]Nc1c([R])cc([R])c(C(=O)[O-])c1C(=O)[O-]</smiles>

1a $\left(\mathrm{R}=\mathrm{Me}, \mathrm{R}_{1}=\mathrm{H}\right)$

$1 b\left(\mathrm{R}=\mathrm{H}, \mathrm{R}_{1}=\mathrm{Hexyl}\right)$

1c $\left(\mathrm{R}=\mathrm{Me}, \mathrm{R}_{1}=\mathrm{Hexyl}\right)$

3AP $\left(\mathrm{R}=\mathrm{R}_{1}=\mathrm{H}\right)$

\section{Phosphonium Quenchers}

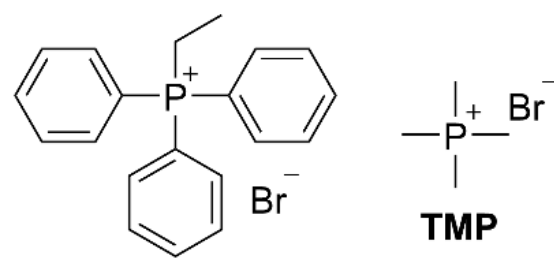

ETPP

Figure 2. Structures of the phthalate emitters and phosphonium quenchers studied.

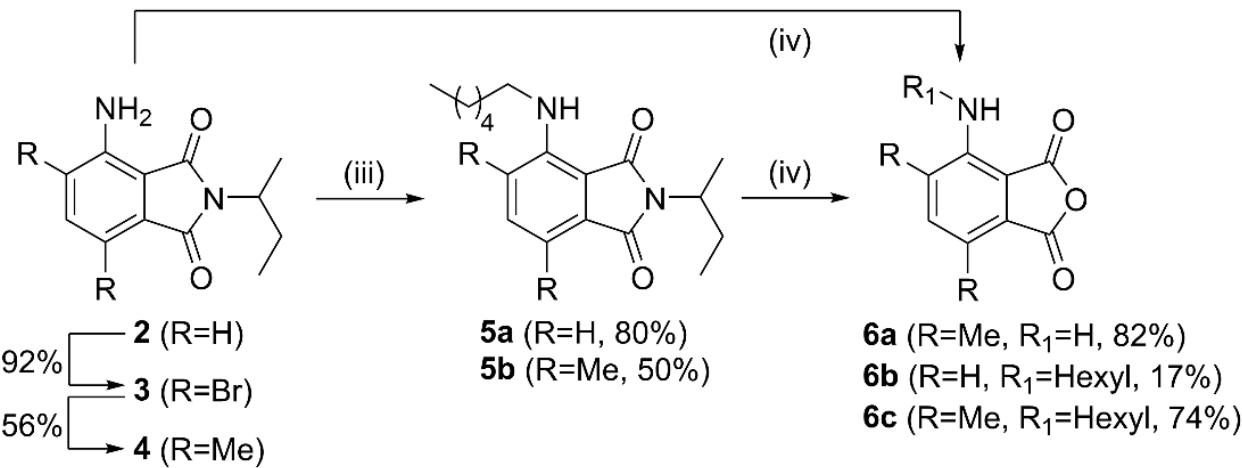

Figure 3. Synthesis of phthalic acid anhydride derivatives 6a-c. Reagents and conditions: (i) $\mathrm{Br}_{2}$, $\mathrm{HOAc}, \mathrm{NaOAc}$, r.t., $18 \mathrm{~h}$, (ii) trimethylboroxine, $\mathrm{Pd}\left(\mathrm{PPh}_{3}\right)_{4}, \mathrm{~K}_{2} \mathrm{CO}_{3}, \mathrm{H}_{2} \mathrm{O}, 1$,4-dioxane $105^{\circ} \mathrm{C}, 18 \mathrm{~h}$, (iii) 1-iodohexane, $\mathrm{NMP}, 110^{\circ} \mathrm{C}, 2 \mathrm{~d}$, (iv) $15 \mathrm{~N}$ aq. $\mathrm{KOH}, \mathrm{EtOH}$, reflux, $3 \mathrm{~d}$.

Steady-state fluorescence and time-resolved experiments were performed for compounds $\mathbf{1 a}-\mathbf{c}$ and $3 \mathrm{AP}$ in phosphate-buffered saline (PBS) at $\mathrm{pH} 8$ to evaluate the possibility of an electron transfer quenching process from the phthalates to the phosphonium cation, using ETPP as the source of phosphonium. The obtained results are shown in Figure 4, Figure S2 in the Supplementary Material, and Table 1. The TMP salt was used as a reference to analyze the effect of the triphenyl-substituent in the quenching process (see Table 1 and Figure S3 in the Supplementary Materials).

Table 1. Quenching rate constants obtained by: ${ }^{a}$ steady state fluorescence $\left(\mathrm{k}_{\mathrm{q}}\right),{ }^{\mathrm{b}}$ time resolved fluorescence $\left(\mathrm{k}_{\mathrm{q}}^{\prime}\right)$.

\begin{tabular}{|c|c|c|c|c|c|c|}
\hline & & & pH 8 ETPP & & pH 8 TMP & \\
\hline Phthalate & $\Phi_{\mathrm{F}} \mathrm{pH} 10$ & $\tau_{\mathrm{o}}(\mathrm{ns})$ & $k_{q}\left(M^{-1} s^{-1}\right)^{a}$ & $k_{q}^{\prime}\left(M^{-1} s^{-1}\right)^{b}$ & $k_{q}\left(M^{-1} s^{-1}\right)^{a}$ & $k_{q}^{\prime}\left(M^{-1} s^{-1}\right)^{b}$ \\
\hline 3AP & 0.30 & 6.1 & $3.7 \times 10^{9}$ & $2.5 \times 10^{9}$ & $2.7 \times 10^{8}$ & $9.0 \times 10^{7}$ \\
\hline $1 a$ & 0.34 & 5.7 & $5.8 \times 10^{9}$ & $3.4 \times 10^{9}$ & - & - \\
\hline $1 b$ & 0.07 & 6.2 & $6.0 \times 10^{9}$ & $5.4 \times 10^{9}$ & - & - \\
\hline 1c & 0.08 & 2.5 & $9.0 \times 10^{9}$ & $8.4 \times 10^{9}$ & - & - \\
\hline
\end{tabular}



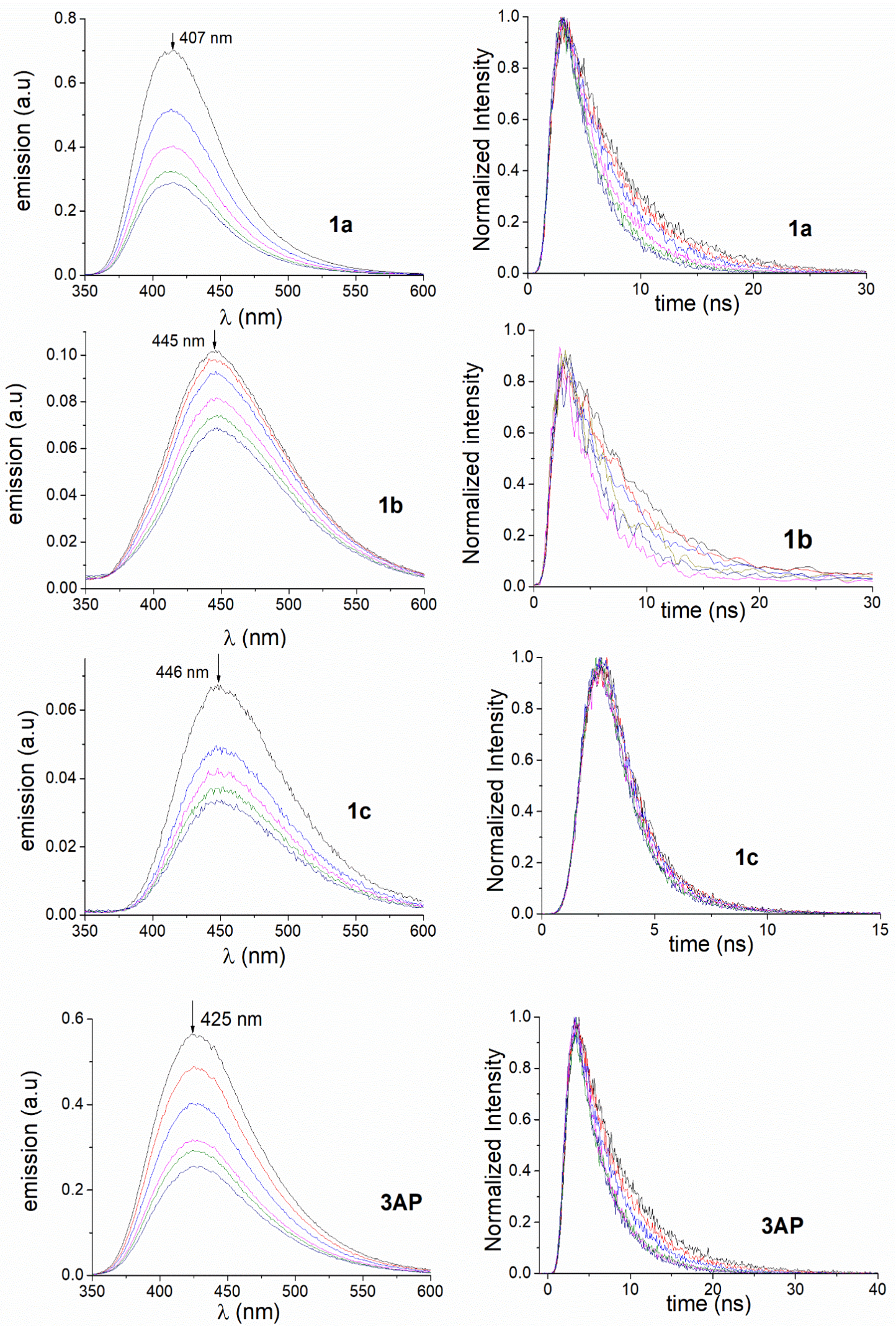

Figure 4. Emission spectra (left) and fluorescence decays (right) for compounds 1a-c and 3AP obtained in PBS $(0.1 \mathrm{mM})$ in the presence of increasing amounts of ETPP $(0-42.1 \mathrm{mM}$; colour codes: $0 \mathrm{mM}$ black line, $4.6 \mathrm{mM}$ red line, $11.4 \mathrm{mM}$ blue line, $22.2 \mathrm{mM}$ pink line, $32.4 \mathrm{mM}$ green line, $42.1 \mathrm{mM}$ navy blue line). 
The marked weakening of phthalate fluorescence upon 3-amino alkylation (1b,c vs. 3AP and 1a) is an interesting observation. Regarding phosphonium-induced quenching, the values shown in the table indicate that the quenching is mainly dynamic. The contribution of static quenching (difference between the $\mathrm{k}_{\mathrm{q}}$ and $\mathrm{k}_{\mathrm{q}}^{\prime}$ series) can, in principle, be attributed to complex formation in the ground state. This effect is less pronounced when there are methyl groups on the aromatic ring and/or an alkyl chain on the amino group, probably due to steric hindrance. The possibility of an apparent static quenching associated with a filter effect can be safely ruled out based on the lack of absorbance variation at the excitation wavelength $(300 \mathrm{~nm})$ upon addition of the phosphonium salt (see Figure S1 in the Supplementary Materials). The fact that electron-donating alkyl substituents, both on the aromatic ring and the amino group, increase the dynamic quenching rate constant is consistent with an electron transfer mechanism. The TMP reference phosphonium salt also quenched the fluorescence of $\mathbf{3 A P}$, but the rate constant was ca. one order of magnitude lower.

The generation of short-lived intermediates from 3AP in the presence of ETPP was investigated by laser flash photolysis (LFP). The transient absorption spectra were monitored upon laser excitation $(\lambda=355 \mathrm{~nm})$ in deaerated PBS at $\mathrm{pH}$. They revealed the formation of a broad shapeless band with a maximum in the $700 \mathrm{~nm}$ region (Figure 5A). This species was ascribed to the solvated electron, based on its disappearance upon bubbling with $\mathrm{N}_{2} \mathrm{O}$ (Figure 5A inset). This observation is proof for photoionization, which was found to be monophotonic by plotting the signal intensity immediately after the laser pulse versus the pulse energy (see Figure S4 in the Supplementary Materials). As expected, the solvated electron was quenched by oxygen with a $\mathrm{k}_{\mathrm{q}}=5.8 \times 10^{9} \mathrm{M}^{-1} \mathrm{~s}^{-1}$ (see Figure S5 in the Supplementary Materials).
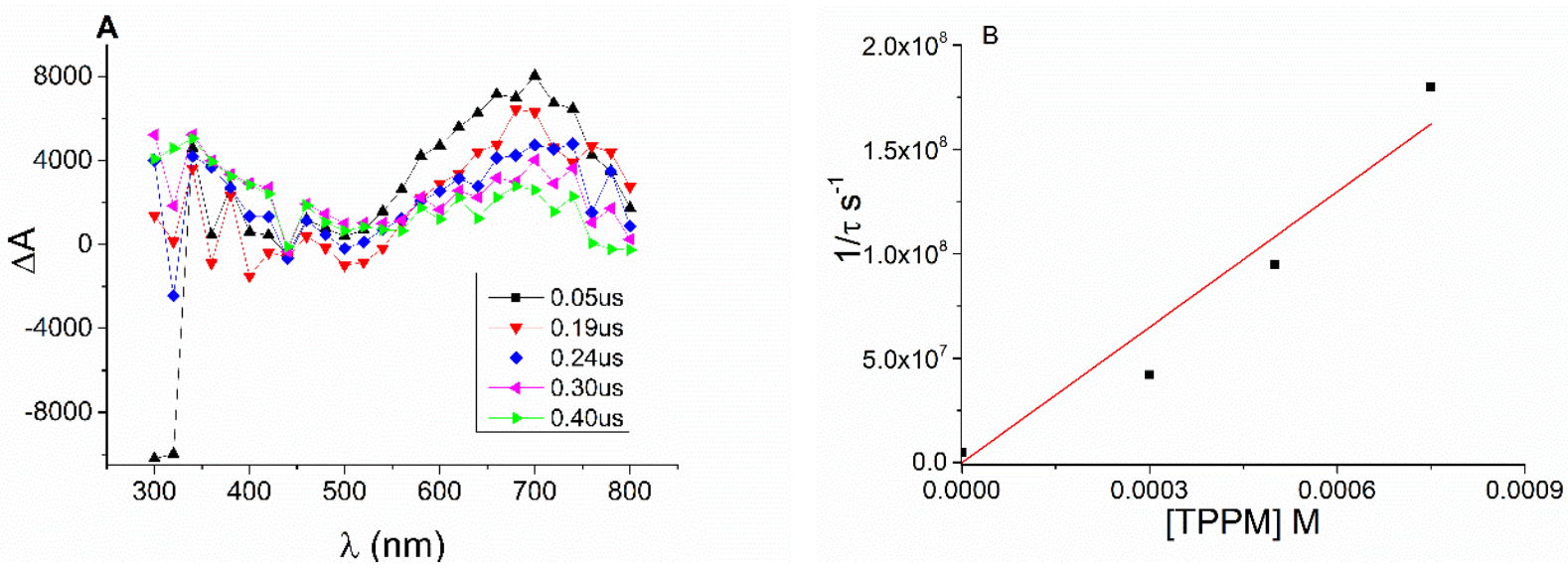

Figure 5. (A) Transient absorption spectra of a $\mathrm{N}_{2}$-bubbled PBS solution of $3 \mathrm{AP}$ at $\mathrm{pH} 8$ at different times after the $355 \mathrm{~nm}$ laser pulse. (B) Stern-Volmer plot for quenching of the solvated electron by ETPP (from 0 to $0.8 \mathrm{mM}$ ) under $\mathrm{N}_{2}$.

To evaluate the reactivity of the solvated electron with ETPP, the quenching rate constant was determined. Hence, the decay was monitored at $700 \mathrm{~nm}$ upon the addition of increasing amounts of ETPP (Figure 5B inset). The corresponding rate constant value was obtained from the slope of the linear plot by representing reciprocal lifetime versus ETPP concentrations (Figure 5B). The quenching rate constant obtained for the reaction of the solvated electron with ETPP was $\mathrm{k}_{\mathrm{q}}=2.2 \times 10^{8} \mathrm{M}^{-1} \mathrm{~s}^{-1}$.

The above results demonstrate that photoionization of $\mathbf{3 A P}$ produces solvated electrons which react readily with ETPP, hence leading to a reduction of the latter. In order to evaluate the feasibility of a direct electron transfer process in the excited state, we made an estimation of the $\Delta \mathrm{G}$ associated to the process by means of the Rehm-Weller equation (Equation (3)).

$$
{ }^{1} \mathbf{3 A P}{ }^{*} \rightarrow \mathbf{3} \mathbf{A P}^{+}+1 \mathrm{e}^{-}
$$




$$
\begin{gathered}
\mathbf{E T P P}^{+}+1 \mathrm{e}^{-} \rightarrow \mathbf{E T P P} \\
\Delta \mathrm{Get}\left(\mathrm{kcal} \mathrm{mol}^{-1}\right)=-23.06 \times\left[\mathrm{E}_{\mathrm{red}}\left(\mathbf{E T P P}^{+} / \mathbf{E T P P}\right)-\mathrm{E}_{\mathrm{red}}\left(\mathbf{3 A P} \mathbf{P}^{+} / \mathbf{3 A P}\right)\right]-\mathrm{E}_{\mathrm{S}}(\mathbf{3 A P})
\end{gathered}
$$

The singlet excited state energy $\left(\mathrm{E}_{\mathrm{S}}\right)$ was determined ca. $72.4 \mathrm{kcal} \mathrm{mol}^{-1}$ from the intersection between the normalized emission and excitation spectra. (see Figure S6 in the Supplementary Materials).

The reduction potentials were experimentally determined by cyclic voltammetry (see Figure S7 in Supplementary Materials), namely: $\mathrm{E}_{\text {red }}\left(\mathbf{E T P P}^{+} / \mathbf{E T P P}\right)=-0.86 \mathrm{~V}$ and $\left.\mathrm{E}_{\text {red }}\left(3 \mathrm{AP}^{+} / 3 \mathrm{AP}\right)\right]=0.68 \mathrm{~V}$.

Using the obtained values for $\mathrm{E}_{\mathrm{S}}$ and $\mathrm{E}_{\mathrm{red}}$, the resulting $\Delta \mathrm{G}$ for the electron transfer process from the singlet excited state was $-37.0 \mathrm{kcal} \mathrm{mol}^{-1}$ indicating that the process is indeed thermodynamically favorable.

To assess the impact of phosphonium quenching on the CL of the commercially available luminol, this was dissolved in aqueous solutions at $\mathrm{pH} 10$, giving a final concentration of $7.5 \mu \mathrm{M}$. Two milliliters were placed in a quartz cuvette, and the CL was manually triggered by the subsequent addition of $\mathrm{H}_{2} \mathrm{O}_{2}$ and $\mathrm{K}_{3}\left[\mathrm{Fe}(\mathrm{CN})_{6}\right]$ while vigorously stirring (Figure 6; black trace). Monitoring of the process was performed using a fluorometer running in the time-based mode (own lamp switched off, $425 \mathrm{~nm}$ as monitoring wavelength). Parallel experiments were carried out where the $\mathrm{CL}$ of luminol was measured in the presence of increasing amounts of ETPP $(0-7.8 \mathrm{mM}$, concentration in the cuvette, colored traces). As a matter of fact, a consistent reduction of luminol's CL in the presence of the phosphonium cation was observed. This is in agreement with the results discussed above on fluorescence quenching of the phthalate emitters by ETPP.

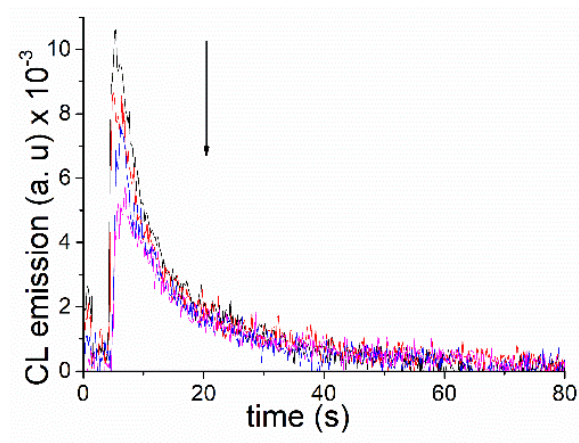

Figure 6. Reduction of luminol's chemiluminescence $(7.5 \mu \mathrm{M})$ in the presence of increasing amounts of ETPP (0-7.8 mM) in aqueous solutions at $\mathrm{pH} 10$.

In summary, phosphonium cations interact with the singlet excited state of phthalates, leading to a partial quenching of their fluorescence. The mechanism is attributed to an excited state electron transfer based on the substituent effects and on the favorable thermodynamics of the process, according to the Rehm-Weller equation. The observed quenching has an impact on the chemiluminescence of the precursor luminols, reducing their efficiency.

The question of whether this intermolecular effect at high phosphonium concentrations can be extrapolated to a possible intramolecular effect in diluted phosphoniumfunctionalized luminols remains to be investigated. It can be envisaged that, when linked together with the cation, luminol might be more efficiently quenched. However, obvious ways to circumvent (or at least mitigate) this possible drawback would be to play with the nature of the phosphonium cation (e.g., alkyl-substituted instead of aryl) or with the length of the linking bridge between the luminol core and the phosphonium moiety (the longer, the better).

In addition, these results emphasize the importance of finding improved luminol derivatives with higher chemiluminescence quantum yields so that the remaining emission after a possible partial quenching is still sufficient for the intended purpose. 


\section{Materials and Methods}

\subsection{General Remarks}

All chemicals were obtained from commercial sources and were used without further purification. Solvents were dried according to published procedures [28]. The course of the reactions was monitored with thin-layer chromatography (TLC), using aluminum sheets $(0.2 \mathrm{~mm})$ coated with silica gel 60 with fluorescence indicator (silica gel 60 F254). Purification of the products was carried out by flash column chromatography, using silica gel 60 (230-400 mesh). Nuclear magnetic resonance (NMR) spectra were obtained with a Bruker Avance $400 \mathrm{MHz}$ (Bruker BioSpin MRI GmbH, Ettlingen, Germany) or a Varian Mercury 200 MHz spectrometer (Varian Inc., Yarnton, UK). Chemical shifts are reported in ppm. High-resolution mass spectral (HRMS) spectra were recorded in a QTOF maXis impact (Bruker) spectrometer under electron spray ionization conditions (the ${ }^{1} \mathrm{H}$ and ${ }^{13} \mathrm{C}$ NMR data and spectra, as well as HRMS data, are reported in Supplementary Materials, Figure S8).

\subsection{Photophysical Studies}

Steady-state and time-resolved fluorescence measurements were performed with a FLS1000 spectrofluorometer (Edinburgh Instruments, Livingston, UK), equipped with an N-DMM double-emission monochromator, an N-G11 PMT-980 detector, and equipped with a pulsed LED $\left(\lambda_{\text {exc }} 300 \mathrm{~nm}\right)$ as an excitation source. The kinetic traces were fitted by one monoexponential decay function, using a deconvolution procedure to separate them from the lamp pulse profile. All experiments were performed in a quartz cuvette of $1 \mathrm{~cm}$ of optical path. These experiments were performed in a PBS solution at $\mathrm{pH} 8$. The phthalate solutions were prepared with a concentration of $10^{-4} \mathrm{M}$, while a stock solution of ETPP $(0.4 \mathrm{M})$ was prepared, so it was only necessary to add microliter volumes $(250 \mu \mathrm{L})$ to the sample cell to obtain the appropriate concentration of the quencher. The rate constants $\left(\mathrm{k}_{\mathrm{q}}\right.$ and $\left.\mathrm{k}_{\mathrm{q}}^{\prime}\right)$ for the reaction were obtained from the Stern-Volmer plots following Equations (4) and (5), respectively:

$$
\begin{gathered}
\mathrm{I}_{0} / \mathrm{I}=1+\mathrm{k}_{\mathrm{q}} \times \tau_{0} \times[\text { ETPP }] \\
\tau_{0} / \tau=1+\mathrm{k}_{\mathrm{q}}^{\prime} \times \tau_{0} \times[\text { ETPP }]
\end{gathered}
$$

where $\mathrm{I}_{0}$ and I are the intensities at the emission maxima in the absence of, and after addition of, a quencher concentration [ETPP], $\tau_{0}$ is the fluorescence lifetime of the phthalate in the absence of ETPP and $\tau$ is the lifetime after addition of a quencher concentration [ETPP].

Monitoring the CL of luminol at $\mathrm{pH} \mathrm{10,} \mathrm{in} \mathrm{the} \mathrm{absence} \mathrm{and} \mathrm{presence} \mathrm{of} \mathrm{ETPP} \mathrm{was}$ performed using the same spectrofluorometer with its own lamp switched off. The set was run in the time-based mode with the detection dialed at $425 \mathrm{~nm}$. Each experiment was performed at least 10 times. For triggering the chemiluminescence, luminols were dissolved in aqueous basic solutions giving a final concentration of $7.5 \mu \mathrm{M}$. Then, $2 \mathrm{~mL}$ of luminol or luminol plus ETPP were introduced in a quartz cuvette and the CL was manually triggered by the addition of $2.5 \mu \mathrm{L}$ of $\mathrm{H}_{2} \mathrm{O}_{2}(50 \% w / w)$ and $8 \mu \mathrm{L}$ of $\mathrm{K}_{3}\left[\mathrm{Fe}(\mathrm{CN})_{6}\right]$ $75 \mathrm{mM}$ while vigorously stirring.

\subsection{Laser Flash Photolysis Studies}

For the detection of transient species, time-resolved kinetic analyses were performed using a laser flash photolysis (LFP) system equipped with a Nd: YAG SL404G-10 Spectron Laser (Lotis Tii, Minsk, Belarus) at the excitation wavelength of $355 \mathrm{~nm}$. The single pulses were of ca. $10 \mathrm{~ns}$ duration, and the energy was lower than $30 \mathrm{~mJ}$ per pulse. The detecting light source was a pulsed Lo255 Oriel Xenon lamp. In addition to the pulsed laser, the LFP included the pulsed Lo255 Oriel Xe lamp (Newport, Irvine, CA, USA), a 77,200 Oriel monochromator, a photomultiplier (Oriel, model 70705PMT) system, and a TDS-640A Tektronix oscilloscope (Betashire, UK). A customized Luzchem Research LFP-111 system was employed to collect and transfer the output signal from the oscilloscope to a personal 
computer to process the data. A quartz cell of $1 \mathrm{~cm}$ optical path length was employed for all kinetic measurements. These experiments were performed in a PBS solution at $\mathrm{pH} 8$, under $\mathrm{N}_{2}$ air (0.0019 $\mathrm{M} \mathrm{O}_{2}$ concentration in solution) and oxygen (0.0091 $\mathrm{M} \mathrm{O}_{2}$ effective concentration in solution). The phthalate solutions were prepared with a concentration of $0.0016 \mathrm{M}$ (absorbance at $\lambda_{\text {exc }}=355 \mathrm{~nm}$ was 0.25$)$, while a stock solution of ETPP $(0.04 \mathrm{M})$ was prepared.

\subsection{Electrochemical Studies}

Cyclic voltammetry measurements were performed with a VersaSTAT 3 potentiostat (Princeton Applied Research, Algete, Madrid, Spain) and using a three-electrode standard configuration with a carbon sheet as working electrode, a platinum wire as a counter electrode, and $\mathrm{Ag} / \mathrm{AgCl}$ in saturated $\mathrm{KCl}$ as the reference electrode. Measurements were carried out on DMF or PBS at pH 8 solutions with $0.1 \mathrm{M} \mathrm{Bu}_{4} \mathrm{NI}$ or $\mathrm{LiClO}_{4}$ as the electrolyte of ETPP or 3AP $(1 \mathrm{mM})$ respectively at a scan rate of $0.05 \mathrm{~V} \cdot \mathrm{s}^{-1}$. All the solutions were previously purged with $\mathrm{N}_{2}$ for at least 15 min before the measurements.

\subsection{Synthesis Procedures}

4-Amino-2-(sec-butyl)isoindoline-1,3-dione 2 was synthesized as previously published [24]. All derivatives were characterized by ${ }^{1} \mathrm{H}$ and ${ }^{13} \mathrm{C}-\mathrm{NMR}$ and ESI-HRMS.

\subsubsection{4-Amino-5,7-dibromo-2-(sec-butyl)isoindoline-1,3-dione (3)}

A round-bottom flask was charged with aminophthalimide 2 ( $1 \mathrm{~g}, 4.6 \mathrm{mmol})$ and sodium acetate $(762 \mathrm{mg}, 9.3 \mathrm{mmol})$ in acetic acid $(11 \mathrm{~mL})$, and the resulting solution was stirred at r.t. for $30 \mathrm{~min}$. Then, a solution of bromine $(0.5 \mathrm{~mL}, 9.4 \mathrm{mmol})$ in acetic acid $(4 \mathrm{~mL})$ was added dropwise, and the reaction mixture was stirred at r.t. for $18 \mathrm{~h}$. After that, the mixture was poured into ice-cold water $(100 \mathrm{~mL})$, forming a yellow precipitate. This was collected by filtration, washed with water and dried under reduced pressure, yielding compound 3 as a yellow powder $(1.6 \mathrm{~g}, 92 \%) .{ }^{1} \mathbf{H}$ NMR $\left(200 \mathrm{MHz}, \mathrm{CDCl}_{3}\right) \delta 7.79(\mathrm{~s}, 1 \mathrm{H}$, $\mathrm{ArH}), 5.77$ (bs, 2H, NH$)_{2}$, 4.34-4.05 (m, 1H, NCH), 2.19-1.89 (m, 1H, $\left.\mathrm{CHCH}_{2} \mathrm{CH}_{3}\right), 1.89-1.63$ $\left(\mathrm{m}, 2 \mathrm{H}, \mathrm{CHCH}_{2} \mathrm{CH}_{3}\right), 1.44\left(\mathrm{~d}, J=6.9 \mathrm{~Hz}, 4 \mathrm{H}, \mathrm{CH}_{3} \mathrm{CH}\right), 0.87\left(\mathrm{t}, J=7.4 \mathrm{~Hz}, 4 \mathrm{H}, \mathrm{CH}_{2} \mathrm{CH}_{3}\right)$. ${ }^{13} \mathrm{C}$ NMR $\left(50 \mathrm{MHz}, \mathrm{CDCl}_{3}\right) \delta 168.38,165.97,142.23,141.02,128.38,115.62,113.53,103.86$, $49.17,26.71,18.34,11.32$. Molecular ion could not be detected on ESI-MS or ESI-HRMS.

\subsubsection{4-Amino-5,7-dimethyl-2-(sec-butyl)isoindoline-1,3-dione (4)}

A round-bottom flask under an inert atmosphere was charged with brominated phthalimide 3 (1.5 g, $4 \mathrm{mmol})$, trimethylboroxine (2.5 M in THF, $2.5 \mathrm{~mL}, 8.8 \mathrm{mmol})$, and potassium carbonate $(3.3 \mathrm{~g}, 24.2 \mathrm{mmol})$ in a mixture of water $(22 \mathrm{~mL})$ and 1,4-dioxane $(22 \mathrm{~mL})$. The solution was purged with argon for approximately $30 \mathrm{~min}$. Tetrakis(triphenylphosphine)palladium $(0)$ (92 $\mathrm{mg}, 0.08 \mathrm{mmol}$ ) was then added and the mixture was purged once again for $15 \mathrm{~min}$. Subsequently, the reaction mixture was stirred under an inert atmosphere at $105^{\circ} \mathrm{C}$ for $18 \mathrm{~h}$. After cooling to ambient temperature, the solvent was partially evaporated and water $(80 \mathrm{~mL})$ was added to the flask. The aqueous phase was extracted with EtOAc $(150 \mathrm{~mL})$. The organic phase was then washed with $1 \mathrm{~N} \mathrm{HCl}(50 \mathrm{~mL})$ and brine $(50 \mathrm{~mL})$, dried over anhydrous $\mathrm{MgSO}_{4}$, filtered and concentrated under reduced pressure. The residue was subjected to column chromatography (P.E./EtOAc 9:1 to 7:3) and, after evaporation of the solvent, 4 was acquired as a yellow solid (552 mg, 56\%). ${ }^{1} \mathbf{H}$ NMR (200 MHz, $\left.\mathrm{CDCl}_{3}\right) \delta 6.98$ (s, 1H, ArH), 5.17 (bs, 2H, NH $), 4.13(\mathrm{q}, J=6.7 \mathrm{~Hz}, 1 \mathrm{H}, \mathrm{NCH}), 2.44\left(\mathrm{~s}, 3 \mathrm{H}, \mathrm{CH}_{3}\right), 2.15(\mathrm{~s}, 3 \mathrm{H}$, $\left.\mathrm{CH}_{3}\right), 1.99\left(\mathrm{~m}, 1 \mathrm{H}, \mathrm{NCHCH}_{2}\right), 1.70\left(\mathrm{~m}, 1 \mathrm{H}, \mathrm{NCHCH}_{2}\right), 1.39\left(\mathrm{~d}, \mathrm{~J}=6.9 \mathrm{~Hz}, 3 \mathrm{H}, \mathrm{CH}_{3} \mathrm{CH}\right), 0.82$ $\left(\mathrm{t}, \mathrm{J}=7.4 \mathrm{~Hz}, 3 \mathrm{H}, \mathrm{CH}_{2} \mathrm{CH}_{3}\right) .{ }^{13} \mathrm{C}$ NMR $\left(50 \mathrm{MHz}_{2} \mathrm{CDCl}_{3}\right) \delta 170.86,169.46,142.26,138.04$, $129.54,126.37,111.02,48.32,29.72,26.96,18.57,16.80,16.42,11.38$. ESI-HRMS $\mathrm{m} / \mathrm{z}$ for $\mathrm{C}_{14} \mathrm{H}_{19} \mathrm{~N}_{2} \mathrm{O}_{2}[\mathrm{M}+\mathrm{H}]^{+}$calcd. 247.1447, found 247.1429. 


\subsubsection{General Procedure for the $N$-alkylation of 4 -aminophthalimides $(\mathbf{5 a}-\mathbf{5 b})$}

Aminophthalimide 2 or 4 ( $2.72 \mathrm{mmol})$ was dissolved in $N$-methyl-pyrrolidone $(0.6 \mathrm{~mL})$. 1-Iodohexane $(0.5 \mathrm{~mL}, 3.3 \mathrm{mmol})$ was added and the reaction mixture was stirred at $110^{\circ} \mathrm{C}$ for two days. After cooling down to ambient temperature, the mixture was quenched with water and was extracted with EtOAc. The organic phase was separated, dried over anhydrous $\mathrm{Na}_{2} \mathrm{SO}_{4}$, filtered and concentrated in vacuum. The residue was subjected to column chromatography (P.E./EtOAc 9:1) and the product (eluted first) was acquired after evaporation of the solvent.

2-(sec-Butyl)-4-(hexylamino)isoindoline-1,3-dione (5a): From aminophthalimide 2 (594 mg). Yellow oil (659 mg, 80\%). ${ }^{1} \mathbf{H}$ NMR $\left(200 \mathrm{MHz} \mathrm{CDCl}_{3}\right) \delta 7.60(\mathrm{t}, J=7.3 \mathrm{~Hz}, 1 \mathrm{H}$, H-6), 7.15 (d, J = 7.2 Hz, 1H, H-5), 6.94 (d, J = 8.8 Hz, 2H, H-7), 6.12 (bs, 1H, NH), 3.29 (t, $\left.J=5.7 \mathrm{~Hz}, 2 \mathrm{H}, \mathrm{NHCH}_{2}\right), 1.81-1.57\left(\mathrm{~m}, 2 \mathrm{H}, \mathrm{NHCH}_{2} \mathrm{CH}_{2}\right), 1.55-1.17\left(\mathrm{~m}, 8 \mathrm{H}, \mathrm{CH}_{2}\right), 0.90(\mathrm{t}$, $\left.J=6.1 \mathrm{~Hz}, 3 \mathrm{H}, \mathrm{CH}_{3}\right) .{ }^{13} \mathrm{C} \mathrm{NMR}\left(50, \mathrm{CDCl}_{3}\right) \delta 171.22,168.45,146.53,135.39,132.87,115.91$, 110.47, 110.36, 48.51, 42.68, 31.57, 29.31, 26.98, 26.71, 22.60, 18.54, 14.05, 11.34. ESI-HRMS $m / z$ for $\mathrm{C}_{18} \mathrm{H}_{27} \mathrm{~N}_{2} \mathrm{O}_{2}[\mathrm{M}+\mathrm{H}]^{+}$calcd. 303.2073, found 303.2078.

2-(sec-Butyl)-4-(hexylamino-5,7-dimehtylisoindoline-1,3-dione (5b): From aminophthalimide 4 (670 mg). Yellow oil (450 mg, 50\%). ${ }^{1} \mathbf{H}$ NMR $\left(200 \mathrm{MHz}, \mathrm{CDCl}_{3}\right) \delta 7.03(\mathrm{~s}, 1 \mathrm{H}$, ArH), 6.09 (bs, 1H, NH), 4.28-4.03 (m, 1H, NCH), 3.29 (t, $\left.J=6.7 \mathrm{~Hz}, 2 \mathrm{H}, \mathrm{NHCH}_{2}\right), 2.48$ $\left(\mathrm{s}, 3 \mathrm{H}, \mathrm{CH}_{3}\right), 2.36\left(\mathrm{~s}, 3 \mathrm{H}, \mathrm{CH}_{3}\right), 2.13-1.90\left(\mathrm{~m}, 1 \mathrm{H}, \mathrm{CHCH}_{2}\right), 1.86-1.68\left(\mathrm{~m}, 1 \mathrm{H}, \mathrm{CHCH}_{2}\right)$, 1.68-1.49 (m, 2H, $\left.\mathrm{NHCH}_{2} \mathrm{CH}_{2}\right), 1.42\left(\mathrm{~d}, \mathrm{~J}=6.9 \mathrm{~Hz}, 3 \mathrm{H}, \mathrm{CH}_{3} \mathrm{CH}\right), 13.5-1.21\left(\mathrm{~m}, 6 \mathrm{H},-\mathrm{CH}_{2}-\right)$, 0.96-0.77 (m, 6H, hexyl- $\mathrm{CH}_{3}$ and $\left.-\mathrm{CH}_{2} \mathrm{CH}_{3}\right) .{ }^{13} \mathrm{C}$ NMR $\left(50 \mathrm{MHz}, \mathrm{CDCl}_{3}\right) \delta 171.21,169.01$, $146.34,140.25,133.38,127.34,125.66,114.93,48.47,47.14,31.66,31.09$, 27.03, 26.59, 22.68, 20.59, 18.61, 16.55, 14.96, 12.04. ESI-HRMS $m / z$ for $\mathrm{C}_{20} \mathrm{H}_{31} \mathrm{~N}_{2} \mathrm{O}_{2}[\mathrm{M}+\mathrm{H}]^{+}$calcd. 330.2307, found 303.2302.

\subsubsection{General Procedure for the Synthesis of 3-Aminophthalic Anhydrides (6a-6c)}

To a solution of aminophthalimide $(0.3 \mathrm{mmol})$ in ethanol $(3 \mathrm{~mL})$ was added an aqueous solution of potassium hydroxide $(15 \mathrm{~N}, 3 \mathrm{~mL})$ and the resulting solution was heated at reflux for 3 days. After cooling to ambient temperature, ethanol was evaporated, water $(10 \mathrm{~mL})$ was added to the flask and the solution was washed with DCM $(3 \times 15 \mathrm{~mL})$. The aqueous phase was collected and acidified with an aqueous solution of $1 \mathrm{~N} \mathrm{HCl}$ until $\mathrm{pH}$ 2. Upon acidification, the aqueous solution slowly turned from colourless to fluorescent green, indicative of the condensation of the phthalic acid to the corresponding anhydride. The solution was then extracted with EtOAc $(3 \times 20 \mathrm{~mL})$. The combined organic phase was dried over anhydrous $\mathrm{MgSO}_{4}$, filtered and concentrated in vacuo. The residue was subjected to column chromatography (P.E./EtOAc 9.5:0.5), the solvent was evaporated and the residue was washed with hexane to yield the desired anhydride.

4-Amino-5,7-dimethylisobenzofuran-1,3-dione (6a): From aminophthalimide 4 (80 mg). Yellow solid (47 mg, 82\%). ${ }^{1} \mathrm{H}$ NMR $\left(200 \mathrm{MHz}, \mathrm{DMSO}-d_{6}\right) \delta 7.34$ (s, 1H, ArH), 6.38 (bs, 2H, $\left.\mathrm{NH}_{2}\right), 2.39\left(\mathrm{~s}, 3 \mathrm{H}, \mathrm{CH}_{3}\right), 2.21\left(\mathrm{~s}, 3 \mathrm{H}, \mathrm{CH}_{3}\right) .{ }^{13} \mathrm{C}$ NMR $\left(50 \mathrm{MHz}, \mathrm{DMSO}-d_{6}\right) \delta 164.41,163.52$, $145.21,139.79,131.94,126.37,124.46,107.69,17.30,15.91$. ESI-HRMS $m / z$ for $\mathrm{C}_{10} \mathrm{H}_{8} \mathrm{NO}_{3}$ [M-H] ${ }^{-}$calcd. 190.0509, found 190.0487 .

4-(Hexylamino)isobenzofuran-1,3-dione (6b): From aminophthalimide $5 \mathbf{a}(91 \mathrm{mg})$. Yellow solid (13 mg, 17\%). ${ }^{1} \mathbf{H}$ NMR (400 MHz, CDCl 3$) \delta 7.59$ (t, J = 7.5 Hz, 1H, H-6), 7.15 $(\mathrm{d}, J=7.1 \mathrm{~Hz}, 1 \mathrm{H}, \mathrm{H}-7), 6.94$ (d, $J=8.5 \mathrm{~Hz}, 1 \mathrm{H}, \mathrm{H}-5), 6.12$ (bs, 1H, NH), 3.29 (t, J = 7.1 Hz, 2H, $\left.\mathrm{NHCH}_{2}\right), 1.69\left(\mathrm{p}, \mathrm{J}=7.3 \mathrm{~Hz}, 2 \mathrm{H}, \mathrm{NHCH}_{2} \mathrm{CH}_{2}\right), 1.47-1.19\left(\mathrm{~m}, 8 \mathrm{H},-\mathrm{CH}_{2}-\right), 0.90(\mathrm{t}, J=7.0 \mathrm{~Hz}$, $\left.3 \mathrm{H}, \mathrm{CH}_{3}\right) .{ }^{13} \mathrm{C}$ NMR $\left(101 \mathrm{MHz}, \mathrm{CDCl}_{3}\right) \delta 165.26,163.59,148.06,137.87,132.06,117.06$, $112.77,109.82,42.93,31.59,29.16,26.71,22.68,14.13$. ESI-HRMS $m / z$ for $\mathrm{C}_{15} \mathrm{H}_{20} \mathrm{NO}_{4}{ }^{-}$ $[\mathrm{M}+\mathrm{MeO}]^{-} 278.1398$, found 278.1368 .

4-(Hexylamino)-5,7-dimethylisobenzofuran-1,3-dione (6c): From aminophthalimide 5b (99 mg). Yellow solid (61 mg, 74\%). ${ }^{1} \mathbf{H}$ NMR $\left(200 \mathrm{MHz}, \mathrm{CDCl}_{3}\right) \delta 7.19(\mathrm{~s}, 1 \mathrm{H}, \mathrm{ArH})$, 5.57 (bs, 1H, NH), $3.46\left(\mathrm{t}, J=7.0 \mathrm{~Hz}, 2 \mathrm{H}, \mathrm{NHCH}_{2}\right), 2.49\left(\mathrm{~s}, 3 \mathrm{H}, \mathrm{CH}_{3}\right), 2.40\left(\mathrm{~s}, 3 \mathrm{H}, \mathrm{CH}_{3}\right)$, 1.69-1.50 (m, 2H, $\left.\mathrm{NHCH}_{2} \mathrm{CH}_{2}\right), 1.48-1.09\left(\mathrm{~m}, 8 \mathrm{H}-\mathrm{CH}_{2}-\right), 0.88\left(\mathrm{t}, \mathrm{J}=6.2 \mathrm{~Hz}, 3 \mathrm{H}, \mathrm{CH}_{2} \mathrm{CH}_{3}\right)$. ${ }^{13} \mathrm{C}$ NMR $\left(50 \mathrm{MHz} \mathrm{CDCl}_{3}\right) \delta 165.10,163.02,147.49,142.05,133.92,129.25,126.20,112.65$, 
47.06, 31.60, 31.10, 26.47, 22.66, 20.01, 17.09, 12.85. ESI-HRMS $m / z$ for $\mathrm{C}_{16} \mathrm{H}_{20} \mathrm{NO}_{3}[\mathrm{M}-\mathrm{H}]^{-}$ calcd 274.1448, found 274.1440 .

\section{Conclusions}

A series of 3-aminophthalates (1a-c) have been prepared in situ via alkaline hydrolysis of the corresponding 3-aminophthalic acid anhydrides. The latter are the hydrolysis products of the analogous substituted 3-aminophthalimides, which derive from $\mathrm{N}$-alkylation and/or Suzuki methylation of the (brominated) parent phthalimide. 3-Aminophthalates' fluorescence is strongly quenched by ethyltriphenylphosphonium cation, with dynamic rate constants in the order of $10^{9} \mathrm{M}^{-1} \mathrm{~s}^{-1}$, close to the diffusion limit. The substituent effects on the quenching efficiency are consistent with a mechanism involving electron transfer from the electron-rich aminophthalic unit to the electron-deficient phosphonium moiety. Accordingly, the chemiluminescence of luminol is indeed significantly reduced in the presence of phosphonium ions. The possible occurrence of this effect has to be taken into consideration when designing mitotropic drugs or diagnostic agents based on fluorescent or chemiluminescent emitters.

Supplementary Materials: The following are available online, Figure S1: Absorption spectra for compound 1a-c and 3AP upon increasing amounts of ETPP; Figure S2: Emission of 3AP and 1a-c at pH 10; Figure S3: Emission and fluorescence decays of 3AP upon increasing amounts of TMP; Figure S4: 3AP signal intensity versus laser energy; Figure S5: 3AP decays monitored at $700 \mathrm{~nm}$ under $\mathrm{N}_{2}$, air, and $\mathrm{O}_{2}$; Figure S6: Absorption and emission spectra of 3AP; Figure S7: Cyclic voltammograms of 3AP and ETPP; Figure S8: ${ }^{1} \mathrm{H},{ }^{13} \mathrm{C}$ NMR spectra.

Author Contributions: G.M.R.-M. performed all the photophysical work. T.M. and A.P. carried out the reactions to obtain the target compounds. G.R. and M.-C.C. supervised, interpreted, and analyzed data from synthetic and photophysical experiments, respectively; G.C.V. and M.A.M. conceived and coordinated the work, discussed the results and wrote the manuscript. All authors have substantially contributed to this work and agree to be accountable for the content. All authors have read and agreed to the published version of the manuscript.

Funding: This project was financially supported by the European Union's Horizon 2020 framework program for research and innovation under grant agreement no. 712921. T.M. and A.P. would like to thank the State Scholarships Foundation (IKY) for financial support through Ph.D. fellowships through the "Strengthening of Human Resources through Doctoral Research" program of the Operational Program "Human Resource Development, Education and Lifelong Learning" 2014-2020, co-financed by the European Union (European Social Fund ESF) and Greek national funds. M.A.M. and G.M.R.-M. thank the Generalitat Valenciana (Prometeo Program/2017/075) for financial support.

Institutional Review Board Statement: Not applicable.

Informed Consent Statement: Not applicable.

Data Availability Statement: The data presented in this study are available in the Materials and Methods section of the article, as well as the Supplementary Materials.

Conflicts of Interest: The authors declare no competing interest.

Sample Availability: Limited samples of all synthesized compounds are available from the authors.

\section{References}

1. Green, D.R.; Reed, J.C. Mitochondria and Apoptosis. Science 1998, 281, 1309-1312. [CrossRef] [PubMed]

2. Bock, F.J.; Tait, S.W.G. Mitochondria as multifaceted regulators of cell death. Nat. Rev. Mol. Cell Biol. 2020, 21, 85-100. [CrossRef]

3. Murphy, M.P. How mitochondria produce reactive oxygen species. Biochem. J. 2009, 417, 1-13. [CrossRef] [PubMed]

4. Szewczyk, A.; Wojtczak, L. Mitochondria as a Pharmacological Target. Pharmacol. Rev. 2002, 54, 101-127. [CrossRef]

5. Zhang, W.; Hu, X.; Shen, Q.; Xing, D. Mitochondria-specific drug release and reactive oxygen species burst induced by polyprodrug nanoreactors can enhance chemotherapy. Nat. Commun. 2019, 10, 1704. [CrossRef]

6. Milane, L.; Trivedi, M.; Singh, A.; Talekar, M.; Amiji, M. Mitochondrial biology, targets, and drug delivery. J. Control. Release 2015, 207, 40-58. [CrossRef] 
7. Ott, M.; Gogvadze, V.; Orrenius, S.; Zhivotovsky, B. Mitochondria, oxidative stress and cell death. Apoptosis 2007, 12, 913-922. [CrossRef] [PubMed]

8. Miyata, Y.; Mukae, Y.; Harada, J.; Matsuda, T.; Mitsunari, K.; Matsuo, T.; Ohba, K.; Sakai, H. Pathological and Pharmacological Roles of Mitochondrial Reactive Oxygen Species in Malignant Neoplasms: Therapies Involving Chemical Compounds, Natural Products, and Photosensitizers. Molecules 2020, 25, 5252. [CrossRef]

9. Smith, R.A.; Hartley, R.C.; Murphy, M.P. Mitochondria-Targeted Small Molecule Therapeutics and Probes. Antioxid. Redox Signal. 2011, 15, 3021-3038. [CrossRef]

10. Zielonka, J.; Joseph, J.; Sikora, A.; Hardy, M.; Ouari, O.; Vasquez-Vivar, J.; Cheng, G.; Lopez, M.; Kalyanaraman, B. MitochondriaTargeted Triphenylphosphonium-Based Compounds: Syntheses, Mechanisms of Action, and Therapeutic and Diagnostic Applications. Chem. Rev. 2017, 117, 10043-10120. [CrossRef]

11. Hoye, A.T.; Davoren, J.E.; Wipf, P.; Fink, M.P.; Kagan, V.E. Targeting Mitochondria. Acc. Chem. Res. 2008, 41, 87-97. [CrossRef]

12. Jean, S.R.; Tulumello, D.V.; Wisnovsky, S.P.; Lei, E.K.; Pereira, M.P.; Kelley, S.O. Molecular Vehicles for Mitochondrial Chemical Biology and Drug Delivery. ACS Chem. Biol. 2014, 9, 323-333. [CrossRef]

13. Lu, P.; Bruno, B.J.; Rabenau, M.; Lim, C.S. Delivery of drugs and macromolecules to the mitochondria for cancer therapy. J. Control. Release 2016, 240, 38-51. [CrossRef]

14. Chen, X.; Tian, X.; Shin, I.; Yoon, J. Fluorescent and luminescent probes for detection of reactive oxygen and nitrogen species Chem. Soc. Rev. 2011, 40, 4783-4804. [CrossRef]

15. Dickinson, B.C.; Srikun, D.; Chang, C.J. Mitochondrial-targeted fluorescent probes for reactive oxygen species. Curr. Opin. Chem. Biol. 2010, 14, 50-56. [CrossRef] [PubMed]

16. Wei, Y.; Liu, Y.; He, Y.; Wang, Y. Mitochondria and lysosome-targetable fluorescent probes for hydrogen peroxide. J. Mater. Chem. B 2021, 9, 908-920. [CrossRef] [PubMed]

17. Yamaguchi, S.; Kishikawa, N.; Ohyama, K.; Ohba, Y.; Kohno, M.; Masuda, T.; Takadate, A.; Nakashima, K.; Kuroda, N. Evaluation of chemiluminescence reagents for selective detection of reactive oxygen species. Anal. Chim. Acta 2010, 665, 74-78. [CrossRef] [PubMed]

18. Dodeigne, C.; Thunus, L.; Lejeune, R. Chemiluminescence as diagnostic tool. A review. Talanta 2000, 51, 415-439. [CrossRef]

19. Khan, P.; Idrees, D.; Moxley, M.A.; Corbett, J.A.; Ahmad, F.; Von Figura, G.; Sly, W.S.; Waheed, A.; Hassan, M.I. Luminol-Based Chemiluminescent Signals: Clinical and Non-clinical Application and Future Uses. Appl. Biochem. Biotechnol. 2014, 173, $333-355$. [CrossRef]

20. Zhang, N.; Francis, K.P.; Prakash, A.; Ansaldi, D. Enhanced detection of myeloperoxidase activity in deep tissues through luminescent excitation of near-infrared nanoparticles. Nat. Med. 2013, 19, 500-505. [CrossRef]

21. Gross, S.; Gammon, S.T.; Moss, B.L.; Rauch, D.; Harding, J.; Heinecke, J.W.; Ratner, L.; Piwnica-Worms, D. Bioluminescence imaging of myeloperoxidase activity in vivo. Nat. Med. 2009, 15, 455-461. [CrossRef] [PubMed]

22. Sivapackiam, J.; Liao, F.; Zhou, D.; Shoghi, K.I.; Gropler, R.J.; Gelman, A.E.; Sharma, V. Galuminox: Preclinical validation of a novel PET tracer for non-invasive imaging of oxidative stress in vivo. Redox Biol. 2020, 37, 101690. [CrossRef] [PubMed]

23. Yang, M.; Huang, J.; Fan, J.; Du, J.; Pu, K.; Peng, X. Chemiluminescence for bioimaging and therapeutics: Recent advances and challenges. Chem. Soc. Rev. 2020, 49, 6800-6815. [CrossRef] [PubMed]

24. Pantelia, A.; Daskalaki, I.; Cuquerella, M.C.; Rotas, G.; Miranda, M.A.; Vougioukalakis, G.C. Synthesis and Chemiluminescent Properties of Amino-Acylated luminol Derivatives Bearing Phosphonium Cations. Molecules 2019, 24, 3957. [CrossRef] [PubMed]

25. Brundrett, R.B.; White, E.H. Synthesis and chemiluminescence of derivatives of luminol and isoluminol. J. Am. Chem. Soc. 1974, 96, 7497-7502. [CrossRef]

26. Griesbeck, A.G.; Díaz-Miara, Y.; Fichtler, R.; von Wangelin, A.J.; Pérez-Ruiz, R.; Sampedro, D. Steric Enhancement of the Chemiluminescence of Luminols. Chem. A Eur. J. 2015, 21, 9975-9979. [CrossRef]

27. Mikroulis, T.; Cuquerella, M.C.; Giussani, A.; Pantelia, A.; Rodríguez-Muñiz, G.M.; Rotas, G.; Roca-Sanjuán, D.; Miranda, M.A.; Vougioukalakis, G.C. Building a Functionalizable, Potent Chemiluminescent Agent: A Rational Design Study on 6,8-Substituted Luminol Derivatives. J. Org. Chem. 2021, 86, 11388-11398. [CrossRef]

28. Armarego, W.L.F.; Chai, C.L.L. Purification of Organic Chemicals in Purification of Laboratory Chemicals, 5th ed.; ButterworthHeinemann: Burlington, MA, USA, 2003; pp. 380-388. 